\section{OPEN ACCESS}

E-ISSN : 2549-6581

Artikel Hasil Penelitian

Diterima : 14 Juli 2017

Direview : 20 Juli 2017

Dimuat : Agustus - November

2017
Journal of Issues in Midwifer

\title{
Pengaruh Pemberian Antibodi Monoklonal Human Zona Pelusida 3 (mAb HZP3) terhadap Jumlah Sel Granulosa pada Ovarium Mencit (Mus Musculus)
}

\author{
Miftahul Jannah ${ }^{1}$, Rismaina Putri ${ }^{1}$, Dewi Ariani ${ }^{1}$ \\ Program Studi S1 Kebidanan Fakultas KedokteranUniversitasBrawijaya, Malang, Jawa Timur, \\ Indonesia \\ Email: jannahmiftah05@gmail.com \\ HP 081233902386
}

\begin{abstract}
The ZP3 antibody is one of the candidate immunocontraception methods. Previous studies have evaluated that ZP3 antibodies may interfere with gap junction function, thus interfering with communication and transport growth factors between granulosa cells and oocytes and hormone profiles. Granulosa cells have a very important role in follicologenesis. The granulosa cells will proliferate and differentiate, producing steroid hormones and expressing the growth factors needed for oocyte development. Development of granulosa cells that are inhibited and not maximal can cause the development of oocytes are not optimal. This study aims to identify the effect of Mab-hZP3 on KL expression in granulosa cells and FSH levels of mice (mus musculus). The research method is posttest only control group design. 48 mice were grouped into 12, ie control (adjuvant), treatment group (mAb hZP3 dose $20 \mu \mathrm{g}, 40 \mu \mathrm{g}$ and $60 \mu \mathrm{g}$ ), the sacrifice of each group was done on days 10, 15 and 20. Calculation of granulosa cell count was done by HE. Mice immunized with various doses of Mab-hZP3 (doses of $20 \mu \mathrm{g}, 40 \mu \mathrm{g}$ and $60 \mu \mathrm{g}$ ) and terminated on days 10, 15 and 20, granulosa cell counts showed no differences showing no significant difference. Mab-hZP3 is produced using a "bacterial system" and acts as a "specific blocker". In conclusion Monoclonal human antibody ZP3 does not increase $K L$ expression and FSH levels. This reinforces the development of Mab as a safe alternative method of contraception.
\end{abstract}

Keywords: immunocontraception, monoclonal antibody, ZP3

\begin{abstract}
ABSTRAK
Antibodi ZP3 merupakan salah satu kandidat metode imunokontrasepsi. Penelitian sebelumnya mengevaluasi bahwa antibodi ZP3 dapat mengganggu fungsi gap junction sehingga mengganggu komunikasi dan transportasi growth factor antara sel granulosa dan oosit serta profil hormon. Sel granulosa memiliki peran yang sangat penting dalam folikulogenesis. Sel granulosa akan berproliferasi dan berdiferensiasi, menghasilkan hormon steroid dan mengekspresikan growth factor yang dibutuhkan untuk perkembangan oosit.
\end{abstract}


Perkembangan sel granulosa yang terhambat dan tidak maksimal dapat menyebabkan perkembangan oosit yang tidak maksimal.Penelitian ini bertujuan untuk mengidentifikasi pengaruh pemberian Mab-hZP3 terhadap ekspresi KL di sel granulosa dan kadar FSH mencit (mus musculus). Metode penelitian adalah posttest only control group design. 48 ekor mencit dikelompokkan menjadi 12, yaitu kontrol (adjuvan), kelompok perlakuan (mAb hZP3 dosis $20 \mu \mathrm{g}, 40 \mu \mathrm{g}$ dan $60 \mu \mathrm{g}$ ), pengorbanan masing masing kelompok dilakukan pada hari ke 10, 15 dan 20. Penghitungan jumlah sel granulosa dilakukan dengan metode HE. Mencit yang diimunisasi dengan berbagai dosis Mab-hZP3 (dosis $20 \mu \mathrm{g}, 40 \mu \mathrm{g}$ dan $60 \mu \mathrm{g}$ ) dan diterminasi pada hari ke 10, 15 dan 20, jumlah sel granulosa tidak menunjukkan perbedaan tidak menunjukkan perbedaan yang signifikan. Mab-hZP3 diproduksi dengan menggunakan "bacterial system" dan berperan sebagai "spesific blocker". Kesimpulannya Monoklonal antibodi human ZP3 tidak meningkatkan ekspresi KL dan kadar FSH. Hal ini memperkuat pengembangan Mab sebagai metode kontrasepsi alternatif yang aman.

Kata kunci: imunokontrasepsi, antibodi monoklonal, ZP3

\section{PENDAHULUAN}

Berdasarkan laporan BKKBN, pencapaian pelayanan peserta KB baru pada tahun 2014 ternyata mengalami penurunan sebesar $4,46 \%$ jika dibandingkan dengan pencapaian peserta KB baru pada tahun 2013. Penurunan pencapaian pelayanan KB tersebut dipengaruhi oleh beberapa faktor, salah satunya adalah ketidaknyamanan yang disebabkan oleh efek samping kontrasepsi ${ }^{1}$.

Imunokontrasepsi merupakan metode yang saat ini dikembangkan dan sesuai untuk mengatasi permasalahan di atas. Metode imunokontrasepsi harus spesifik, aman, reversibel dan pemberian 1-2 kali penyuntikan sudah dapat mencegah kehamilan dengan efektif dalam waktu yang cukup lama $( \pm 12$ bulan) ${ }^{18,31,26}$. ZP3 merupakan salah satu kandidat imunokontrasepsi. Antibodi ZP3 mampu berikatan dengan gugus glukosa yang terdapat di permukaan ZP dan menutupi reseptor sperma sehingga tidak dapat dikenali oleh sperma. Selain itu, ZP akan mengeras dan mencegah penetrasi sperma ke ZP ${ }^{5,6,7}$.

Pada penelitian in vitro, folikel preantral yang dikembangkan dalam medium yang telah ditambahkan antibodi ZP3 menunjukkan diameter lapisan ZP yang lebih kecil. Selain itu,
ZP tampak lebih tipis dari normal dan perkembangan gap junction (GJ) dan Transzona Process (TZP) terganggu 8,9,10. GJ dan TZP berperan penting dalam komunikasi antara sel granulosa-oosit dan antar sel granulosa dan transportasi growth factors ${ }^{11,12,13}$ Perkembangan GJ dan TZP, yang tidak normal selama folikulogenesis dapat menghambat perkembangan folikel dan oosit. Perkembangan folikel dan oosit menjadi matur dan siap dibuahi dipengaruhi oleh banyak faktor, diantaranya adalah interaksi antara oosit dengan sel-sel di sekelilingnya yaitu sel granulosa dan sel teka serta growth factors yang dibutuhkan oleh folikel dan oosit untuk berkembang. Interaksi antara sel granulosa dengan oosit berperan sangat penting dalam proses folikulogenesis. Growth factors yang dihasilkan oleh oosit akan berpengaruh terhadap proliferasi dan diferensiasi dari sel granulosa dan perkembangan sel granulosa tersebut memberikan timbal balik terhadap perkembangan oosit ${ }^{14,15,16,17,18}$.

Pemberian antibodi monoklonal bZP3 (Mab-bZP3) mampu mencegah $100 \%$ kebuntingan pada tikus hingga hari ke 63 dan pada hari ke 128 tingkat infertilitas akan menurun menjadi $67 \%$ 19. Selain itu, East et al. (1985) melaporkan pemberian Mab mZP3 
dapat menghambat $100 \%$ fertilisasi pada mencit. Meskipun studi tentang keefektifan Mab ZP3 telah dilakukan, penelitian tentang pengaruh antibodi monoklonal ZP3 terhadap komponenkomponen yang terlibat dalam proses folikulogenesis terutama adalah $\mathrm{KL}$ dan FSH masih sangat terbatas.

\section{METODE PENELITIAN}

\section{Desain penelitian}

Penelitian ini menggunakan penelitian eksperimental laboratorium dengan desain true experimental dan pendekatan post test only control group design.

\section{Sasaran Penelitian}

Mencit yang digunakan adalah mencit pernah melahirkan dengan bobot 2025 gram, dibagi menjadi 12 kelompok (@ kelompok : 4 ekor).

\section{Tehnik Pengumpulan Data}

Mencit diinjeksi dengan dengan MabhZP3 dosis $20 \mu \mathrm{g}, 40 \mu \mathrm{g}, 60 \mu \mathrm{g}$ dan kelompok kontrol (Injeksi $50 \mu \mathrm{L}$ Adjuvant $\mathrm{Al}(\mathrm{OH}) 3+50 \mu \mathrm{L}$ Tris $\mathrm{Hcl})$, diterminasi pada siklus pro estrus ke2 , ke-3 dan ke-4. Penghitungan jumlah sel granulosa dilakukan dengan metode $\mathrm{HE}^{20,21}$.

\section{Tehnik Analisis Data}

Hasil penelitian akan diuji normalitas dengan uji Saphiro-Wilk, kemudian dianalisis dengan menggunakan uji Anova dan Tukey $5 \%$.

\section{HASIL PENELITIAN \\ Sel Granulosa}

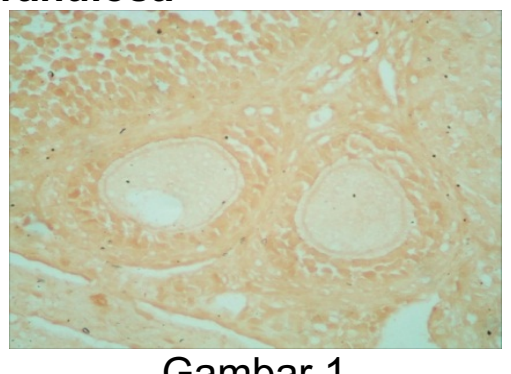

Gambar 1

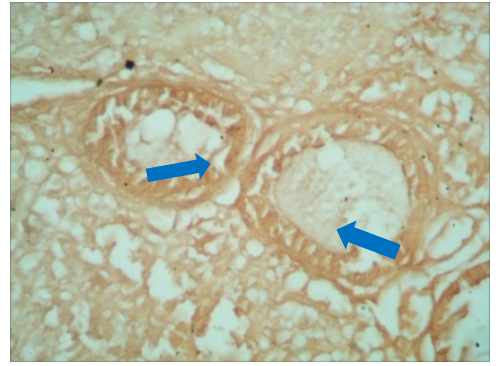

Gambar 2

Gambar 1 adalah kelompok kontrol dan 2 adalah kelompok perlakuan. Tanda panah biru (gambar 2) menunjukkan sel granulosa ovarium mencit yang diinjeksi Mab-hZP3.

\section{Pengaruh Mab-hZP3 Berbagai Dosis dan Waktu Pengamatan terhadap jumlah sel granulosa Histogram Pengaruh Mab-Hzp3 Berbagai Dosis terhadap Jumlah Sel Granulosa}

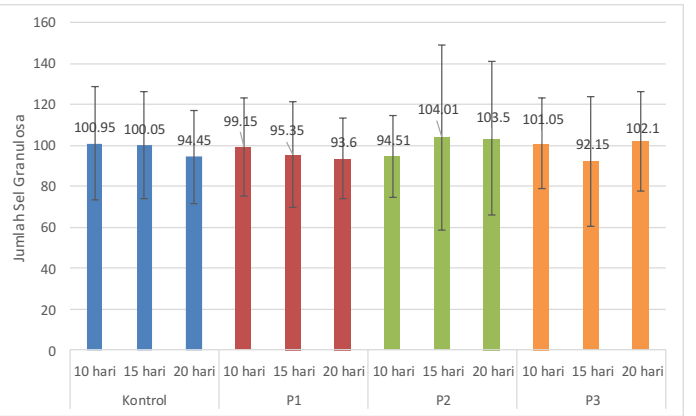

Berdasarkan histogram pengaruh Mab-hZP3 berbagai dosis terhadap jumlah sel granulosa ditunjukkan bahwa kelompok kontrol memiliki ratarata jumlah sel granulosa sebesar 98.48. Pemberian Mab-hZP3 dosis 40 $\mu \mathrm{g}$ (P2) terlihat terjadi peningkatan Jumlah Sel Granulosa sedangkan pada pemberian Mab-hZP3 dengan dosis $10 \mu \mathrm{g}$ (P1) dan $60 \mu \mathrm{g}$ (P3), terjadi penurunan Jumlah Sel Granulosa. Berdasarkan waktu pengamatan, ditunjukkan bahwa pada waktu pengamatan 10 hari, didapatkan rata-rata Jumlah Sel Granulosa tertinggi yakni sebesar 98.92. Kemudian, pada waktu pengamatan 15 hari terjadi sedikit penurunan Jumlah Sel Granulosa dan pada waktu pengamatan 20 hari terjadi sedikit peningkatan jumlah sel granulosa. 
Berdasarkan histogram pengaruh interaksi Mab-hZP3 berbagai dosis dengan waktu pengamatan terhadap Jumlah Sel Granulosa pada Gambar 4.3 di atas, ditunjukkan bahwa kelompok kontrol memiliki rata-rata Jumlah Sel Granulosa yang relatif sama dengan kelompok pemberian Mab-hZP3 berbagai dosis. Dari pengujian ini terbukti bahwa perubahan Jumlah Sel Granulosa seiring peningkatan dosis Mab-hZP3 dan waktu pengamatan secara statistik tidak signifikan ( $p$-value $=0,225>0.05)$.

Kelompok dosis $20 \mu \mathrm{g}$ hari ke 10 menunjukkan sel granulosa yang mengekspresikan $\mathrm{KL}$ lebih tinggi daripada kelompok kontrol dan menurun pada kelompok dosis $40 \mu \mathrm{g}$ dan $60 \mu \mathrm{g}$ pada hari yang sama. Pada terminasi hari ke 15 , kelompok dosis $20 \mu \mathrm{g}, 40 \mu \mathrm{g}$ dan $60 \mu \mathrm{g}$ memiliki sel granulosa yang mengekspresikan $\mathrm{KL}$ yang lebih rendah dibandingkan dengan kelompok kontrol. Sedangkan pada hari ke 20 , sel granulosa yang mengekspresikan $\mathrm{KL}$ pada kelompok dosis $40 \mathrm{\mu g}$ hampir sama dengan kelompok kontrol dan pada dosis 20 $\mu \mathrm{g}$ dan $60 \mu \mathrm{g}$ lebih tinggi dibandingkan dengan kelompok kontrol. Meskipun demikian, sel granulosa yang mengekspresikan $\mathrm{KL}$ pada kelompok kontrol dan kelompok perlakuan dengan berbagai dosis dan waktu pengamatan tidak memiliki perbedaan yang signifikan $(p$-value $=0,992>0.05)$.

\section{PEMBAHASAN}

Zona pelusida tidak hanya memiliki peran dan fungsi di dalam proses awal fertilisasi tetapi juga pada saat folikulogenesis dan masa perkembangan embrio. Pada folikulogenesis, ZP bersama dengan gap junction memiliki peran dalam proses komunikasi antar sel. Gap junction berfungsi sebagai channel dalam transportasi molekul dan growth factor baik antara sel granulosa dengan sel oosit maupun antar sel granulosa. ZP sebagai matriks ekstraseluler memiliki fungsi untuk menstabilkan gap junction ${ }^{8}$. Kit ligand merupakan salah satu growth factor yang memiliki peranan di dalam proses folikulogenesis. Keseimbangan antara ekspresi KL, GDF-9 dan BMP15 akan mempengaruhi proses proliferasi dan diferensiasi sel granulosa serta rekruitmen sel teka ${ }^{15,16,17,18}$.

Hasil studi ini menunjukkan bahwa pemberian Mab-hZP3 pada mencit tidak mempengaruhi jumlah sel granulosa pada ovarium. Jumlah sel granulosa pada kelompok perlakuan tidak berbeda signifikan dengan kelompok kontrol (Gambar 2)

Antibodi ZP3 yang berikatan dengan permukaan epitop ZP akan menstimulasi peningkatan kalsium intraseluler sehingga terjadi eksositosis granul. Hal ini dapat menyebabkan pelepasan enzim yang bekerja pada glikoprotein zona pelusida sehingga permukaan ZP mengeras dan mencegah terjadinya polispermi ${ }^{3}$. Borillo et al. (2008) melaporkan bahwa pengaruh ikatan IgG ZP3 terhadap folikulogenesis dipengaruhi oleh waktu terjadinya ikatan tersebut di tahapan folikulogenesis. Jika IgG ZP3 berikatan dengan ZP folikel pada fase antral dan preovulatori maka lgG ZP3 tidak akan mengganggu proses sintesis $\mathrm{ZP}$. Namun, jika lgG ZP3 berikatan dengan ZP folikel pada fase preantral maka hal tersebut dapat mengganggu proses sintesis ZP dan ZP tidak terbentuk sempurna. Hal ini dapat mempengaruhi gap junction antara oosit dan sel granulosa ${ }^{8,9,10}$.

Pada studi yang dilakukan O'Leary et al (2008), didapatkan hasil bahwa pada hari ke 21 pasca pemberian imunisasi rMCMV mZP3 dapat menyebabkan penurunan ekspresi Gjal, GDF-9 dan NOBOX. 
Penurunan ekspresi Gjaldapat menyebabkan rendahnya ekspresi Cx43 dan ekspresi GDF-9 yang berakibat pada terhambatnya perkembangan folikel. Ekspresi GDF-9 yang berkurang di oosit dapat menyebabkan terjadinya peningkatan ekspresi KL di sel granulosa ${ }^{23}$.

Pada terminasi hari ke 15, kelompok kontrol memiliki jumlah sel granulosa yang lebih tinggi dibandingkan dengan kelompok dosis $20 \mu \mathrm{g}$, dan $60 \mu \mathrm{g}$, sedangkan pada hari ke 20, jumlah sel granulosa pada kelompok dosis $40 \mu \mathrm{gg}$ lebih tinggi dibandingkan dengan kelompok kontrol. Namun, lebih tinggi atau rendahnya jumlah sel granulosa pada kelompok perlakuan dengan berbagai dosis dan waktu pengamatan dibandingkan dengan kelompok kontrol tidak berbeda secara signifikan. Perbedaan jumlah sel granulosa mungkin dipengaruhi oleh periode efek kontraseptif atau periode efektifitas antibodi monoklonal.

$$
\text { Greenhouse et al. }
$$
melaporkan bahwa pemberian Mab mZP3 dengan dosis $0,8 \mathrm{mg}$ dalam 0,5 $\mathrm{ml}$ cairan asites dapat menghambat fertilisasi hingga hari ke 35-80 hari pasca injeksi Mab-mZP3. Hasil yang sama juga didapatkan dari ekspreimen yang dilakukan East et al. (1984) bahwa injeksi Mab-mZP3 dengan dosis $250 \mu \mathrm{g}$ dapat memberikan efek kontrasepsi terjadi hingga hari ke 4080 pasca pemberian Mab mZP3. Tidak terganggunya proliferasi sel granulosa pada kelompok perlakuan karena tidak adanya efek dari Mab-hZP3 atau sudah tidak terdapatnya antibodi, tidak diperiksa secara pasti dalam studi kami. Namun, pemberian antibodi yang homolog secara intravena pada mencit memiliki waktu paruh 2-5 hari dan metode pemberian antibodi dapat mempengaruhi waktu paruh tersebut ${ }^{24}$.

Hal tersebut didukung oleh penelitian yang dilakukan oleh
Tsunoda and Chang (1978). Dalam studi tersebut, mencit yang diberi perlakuan dengan antibodi spesifik secara oral, IP, SC dan IM, didapatkan hasil bahwa antibodi melalui oral tidak menghambat fertilisasi. Sedangkan untuk IP, SC dan IM dapat menghambat fertilisasi sebesar $68 \%$, $60 \%$ dan $58 \%$ dengan dosis $0,05 \mathrm{ml}$ dan memiliki efek kontrasepsi 25-30 hari.

Hal serupa ditunjukkan oleh hasil studi yang dilakukan oleh East et al. (1985) terhadap mencit BALB/c yang diberikan injeksi antibodi monoklonal mZP3. Dari studi tersebut didapatkan hasil bahwa antibodi monoklonal mZP3 efektif menghambat fertilisasi dan tidak mempengaruhi histologi ovarium serta proses folikulogenesis ${ }^{14}$. Hasil yang sama dilaporkan oleh Greenhouse et al. (1999) bahwa pemberian Mab-mZP3 dan hZP3 juga efektif menghambat fertilisasi, tidak merubah histologi ovarium dan tidak menggangu perkembangan folikel. Selain itu, antibodi monoklonal yang diberikan setelah fertilisasi tidak menyebabkan kerusakan atau gangguan pada perkembangan embrio. East et al. (1984) juga melaporkan bahwa jumlah antibodi monoklonal yang dibutuhkan untuk mengganggu fertilisasi adalah sangat sedikit. Selain itu, meskipun dalam studinya menggunakan dosis $250 \mu \mathrm{g}$ East et al. (1984) menyampaikan bahwa hasil yang hampir sama juga didapatkan dengan menggunakan 10 $\mu \mathrm{g}$ antibodi monoklonal.

Alasan lain dimungkinkan karena antibodi monoklonal memiliki sifat spesifik sehingga meminimalkan efek atau dampak ke komponen lainnya. Pemberian Mab ZP3 untuk imunokontrasepsi dapat menghambat fertilisasi dengan berperan sebagai "spesific block" daerah yang berikatan dengan sperma pada zona pelusida karena ZP3 merupakan resptor utama 
sperma $^{15}$. Mab-hZP3 yang digunakan dalam penelitian ini diproduksi dengan mengkloning hZP3 dan mengekspresikannya di dalam plasmid bakteri atau bacterial system yang dapat menghalangi proses glikosilasi. Hal tersebut dapat mengurangi kekuatan ikatan Mab ZP3 ke sperm binding site karena seperti yang dilaporkan Florman and Wassarman bahwa gugus karbohidrat dari ZP3 merupakan mediator dari sperm binding. Meskipun demikian, faktor tersebut tidak mengurangi efektifitas imunokontrasepsi karena mekanisme penghambatan fertilisasi pada imunokontrasepsi tidak hanya melalui Mab ZP3 sebagai "spesific block" reseptor sperma tetapi juga pencegahan penetrasi sperma ke zona pelusida yang disebabkan oleh aktivasi oosit dan reaksi kortikal dini ${ }^{15}$.

\section{KESIMPULAN}

Data hasil penelitian ini mendukung pengembangan antibodi monoklonal ZP3 sebagai metode imunokontrasepsi alternatif untuk mengatasi permasalahan efek samping. Meskipun demikian, perlu dilakukan studi yang intensif titer antibodi dan efek pengerasan ZP terhadap folikulogensis.

\section{KONFLIK KEPENTINGAN}

Tidak ada konflik kepentingan dalam penelitian ini..

\section{DAFTAR PUSTAKA}

[1] BKKBN. 2014. Laporan Umpan Balik Pelayanan Kontrasepsi 2014. Kementerian Kesehatan Republik Indonesia: Jakarta.

[2] Gupta, Satish. K., Gupta, N., Suman, P., Choudhury, S., Prakash, K., Gupta, T., Sriraman, R., Nagendrakumar, S.B., Srinivasan., V.A. 2011. Zona Pellucida-Based Contraceptive
Vaccines for Human and Animal Utility. Journal of Reproductive Immunology. 88:240-246.

[3] Spieler, J. 1987. Development of Immunological Methods of Fertility Regulation. Bulletin of The World Health Organization. 65 (6) : 779-783

[4] Naz, R.K and Rajesh, C. 2004. Passive Immunization for Immunocontraception:. Lesson Learned from Infectious Diseases. Frontiers in Bioscience. 9(1): 2457-2465.

[5] Barber, M.R. and Fayrer-Hosken, R.A. 2000. Possible Mechanism of Mammalian Immunocontraception. Journal of Reproductive Immunology. 46:103-124

[6] East,.I.J., Mattison, D.R., and Dean, J. 1984. Monoclonal Antibodies to the Major Protein of the Murine Zona Pellucida: Effects on Fertilization and Early Development. Developmental Biology. 104: 49-56.

[7] East,.I.J., Gulyas, B.J., and Dean, J. 1985. Monoclonal Antibodies to the Murine Zona Pellucida with Sperm Receptor Activity: Effects on Fertilization and Early Development. Developmental Biology. 109: 268-273.

[8] Borillo, J., Coonrod, S.A., Wu J., Zhou, C. and Lou, Y. 2008. Antibodies to Two ZP3 B Cell Epitopes Affect Zona Pelusida Assembly. Journal of Reproductive Immunology. 78 (2):149-157.

[9] Calongos, G., Hasegawa, A., Komori, S., and Koyama, K. 2009. Harmful Effects of Anti-Zona Pellucida Antibodies in Folliculogenesis, Oogenesis, and Fertilization. Journal of Reproductive Immunology. 79: 148-155. 
[10] Lloyd, M.L., Papadimitrou, J.M., O'Leary, S., Robertson, S.A., and Shellam, G.R. 2010. Immunoglobulin to Zona Pellucida 3 Mediates Ovarian Damage and Infertility after Contraceptive Vaccination in Mice. Journal of Autoimmunity. 35: 77-85.

[11] Gershon, E., Placks, V., and Dekel, N. 2008. Gap Junction in The Ovary: Expression, Localization and Function. Molecular and Cellular Endocrinology. 282: 18-25.

[12] Gittens, J.E.I., Barr, K.J., Vanderhyden, B.C., Kidder, G,M. 2004. Interplay Between Paracrine Signaling and Gap Junctional Communication in Ovarian Follicles. Journal of Cell Science. (1):114-122.

[13] Kidder G.M., and Mhawi, A.A. 2002. Gap Junctions and Ovarian Folliculogenesis. Rerpoduction. 123: 613-620.

[14] Celestino, J.J.H., Matos, M.H.T., Saraiva, M.V.A., and Figueiredo, J.R. 2009. Regulation of Ovarian Folliculogenesis by Kit Ligand and The c-Kit System in Mammals. Animal Reproduction. 6: 431-439.

[15] Jones, R.L. and Pepling, M.E. 2013. KIT Signaling Regulates Primordial Follicle Formation in The Neonatal Mouse Ovary. Developmental Biology. 382: 186-197.

[16] Sanchez, F., and Smitz, J. 2012. Molecular Control of Oogenesis. Biochimica et Biophysica Acta. 1822:1896-1912.

[17] Strauss, F.J., Williams, J.C. 2014. The Ovarian Life Cycle in Yen and Jaffe's Reproductive Endocrinology, $5^{\text {th }}$ Ed; 213-253.

[18] Tsunoda, y. And Chang, M.C. 1978. Effect of Antisera against Eggs and Zonae Pellucidae on
Fertilization and Development of Mouse Eggs in vivo and Culture. J. Reprod. Fert. 54: 233-237

[19] Hutt, K.J., McLaughlin, E.A., and Holland, M.K. 2006. Kit Ligand and c-Kit Have Diverse Roles During Mammalian Oogenesis and Folliculogenesis. Molecular Human Reproduction. 12: 61-69.

[20] Dabbs, David. 2014. Diagnostic Immunohistochemistry:

Theranostic and Genomic Applications. $4^{\text {th }} \mathrm{Ed}$.

[21] McPherson, R.A., and Pincus, M.R. 2011. Henry's Clinical Diagnosis and Management Laboratory Methods. $22^{\text {nd }}$ Ed.

[22] Dahlan, Sopiyudin. 2013. Statistik untuk Kedokteran dan Kesehatan. Deskriptif, Bivariat dan Multivariat, Dilengkapi Aplikasi dengan menggunakan SPSS. Salemba Medika. Jakarta.

[23] O'Leary, S., Lloyd, M.L., Shellam, G.R., and Robertson, S.A. 2008. Immunization with Recombinant Murine Cytomegalovirus Expressing Murine Zona Pellucida 3 Cause Permanent Infertility in BALB?c Mice Due to Follicle Depletion anf Ovulation Failure. Biology of Reproduction 79: 849-860.

[24] Waldmann, T.A., and Stober, W.A. 1969. Metabolism of Immunoglobulins. Progr. Allergy. 13: 1-110. 